\title{
Professionals without a profession
}

Occupational safety and health professionals in Denmark

Madsen, Christian Uhrenholdt; Hasle, Peter; Limborg, Hans Jørgen

\section{Published in:}

Safety Science

DOI:

10.1016/j.ssci.2018.12.010

Publication date:

2019

\section{Document Version}

Early version, also known as pre-print

Citation for published version (APA):

Madsen, C. U., Hasle, P., \& Limborg, H. J. (2019). Professionals without a profession: Occupational safety and health professionals in Denmark. Safety Science, 113, 356-361. https://doi.org/10.1016/j.ssci.2018.12.010

\section{General rights}

Copyright and moral rights for the publications made accessible in the public portal are retained by the authors and/or other copyright owners and it is a condition of accessing publications that users recognise and abide by the legal requirements associated with these rights.

- Users may download and print one copy of any publication from the public portal for the purpose of private study or research.

- You may not further distribute the material or use it for any profit-making activity or commercial gain.

- You may freely distribute the URL identifying the publication in the public portal.

\section{Take down policy}

If you believe that this document breaches copyright please contact rucforsk@kb.dk providing details, and we will remove access to the work immediately and investigate your claim. 


\section{Professionals without a profession}

Occupational safety and health professionals in Denmark

Madsen, Christian Uhrenholdt; Hasle, Peter; Limborg, Hans Jørgen

Published in:

Safety Science

DOI (link to publication from Publisher):

10.1016/j.ssci.2018.12.010

Creative Commons License

Unspecified

Publication date:

2019

\section{Document Version}

Early version, also known as pre-print

Link to publication from Aalborg University

Citation for published version (APA):

Madsen, C. U., Hasle, P., \& Limborg, H. J. (2019). Professionals without a profession: Occupational safety and health professionals in Denmark. Safety Science, 113, 356-361. https://doi.org/10.1016/j.ssci.2018.12.010

\section{General rights}

Copyright and moral rights for the publications made accessible in the public portal are retained by the authors and/or other copyright owners and it is a condition of accessing publications that users recognise and abide by the legal requirements associated with these rights.

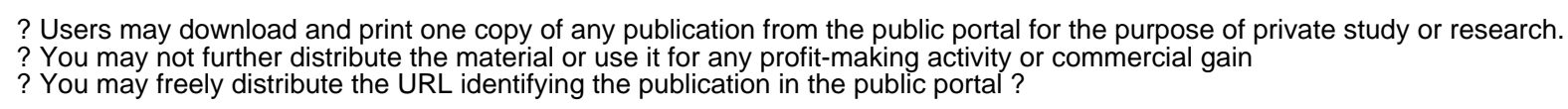

? Users may download and print one copy of any publication from the public portal for the purpose of private study or research.

? You may not further distribute the material or use it for any profit-making activity or commercial gain

? You may freely distribute the URL identifying the publication in the public portal ?

\section{Take down policy}

If you believe that this document breaches copyright please contact us at vbn@aub.aau.dk providing details, and we will remove access to the work immediately and investigate your claim. 


\title{
Professionals without a profession: Occupa- tional health and safety professionals in Den- mark
}

\author{
Christian Uhrenholdt Madsen ${ }^{\mathrm{a}}$ \\ Peter Hasle ${ }^{\mathrm{a}}$ \\ Hans Jørgen Limborg ${ }^{\text {bc }}$
}

a Department of Materials and Production, Aalborg University, AC Meyers Vænge 15, 2450 Copenhagen SV

b Team Working Life, Høffdingsvej 22, 1. 2500 Valby

c Department of People and Technology Roskilde University

\begin{abstract}
:
In this essay we describe the development of health and safety professionals in Denmark. We show how the historical particularities of the so-called 'Danish model', compromises between various health and safety stakeholders, and a lack of pure health and safety educations led to the establishment of an occupational group of professionals characterized by heterogeneity in backgrounds and multidisciplinarity in approaches and methods.

Then we discuss how recent tendencies to the mainstreaming of enterprises' health and safety efforts have challenged the composition of the health and safety professionals, and made other types of professionals competitors in terms of solving health and safety issues. In the essay we propose a conceptual model that combines insights from new institutional theory on fields and knowledge on the tasks of health and safety professionals. In this way the model helps us illustrate the relationship between health and safety professionals and their competitors in the health and safety work within Danish enterprises.
\end{abstract}

Finally we discuss if and how a further professionalization could take place in the Danish context 


\section{Introduction}

Health and safety professionals are widespread in Danish enterprises, but they do not belong to any profession. That does not mean that there are no actors inside and outside the walls of Danish organizations working with health and safety issues on a full-time basis. Nor does it mean that these actors are not competent or "good" at what they do. We do not mean that there is not a sprawling and productive occupational community (Van Maanen \& Barley, 1984) with meetings, conferences, and institutions in which these actors take part. However, there is not one sedimented "profession" of company-centered health and safety actors in Denmark that has emerged over the years and slowly institutionalized values, frameworks, and approaches as the way to "do" health and safety work within organizations as one would theoretically expect a profession to do (Muzio \& Kirkpatrick, 2011). Instead, from early on, the Danish health and safety community has been characterized by multi-disciplinarity, by a heterogeneous group of actors with professional backgrounds in social, technical, natural, and health fields.

Classic sociology of professions describes how professions are delimited and defined by several different variables. Examples are common educational certification, specialized and inimitable skills, and clear boundaries with other professions and occupational groups (Evetts, 2011). In this view, professions and their members are viewed as opposed forces to other governing logics such as the market or the organizational bureaucracies (Freidson, 2001). Thus, they do not necessarily share the values and goals of the organizations in which they are working. It follows from this view that professionals import values, tools, and knowledge from institutions and entities such as universities and professional associations and not necessarily from the organizations in which they are working. Furthermore, membership in professions is normally seen as restricted for people without a specific type of accreditation, license, or educational background (Giddens, 1989).

In other European countries (e.g., the Netherlands, Germany, UK) a stronger degree of professionalization characterizes the group of health and safety advisors, first, by the early establishments of professional associations (Hale \& Harvey, 2012) and, second, by the establishment of university degrees in safety science and ergonomics from the 1970s (Provan, Dekker, \& Rae, 2017). Both factors helped demarcate and distinguish the profession of safety and health experts from related and neighboring fields (e.g., occupational hygienists and occupational medicine) (Hale \& Harvey, 2012). In Denmark, however, no formal profession of internal safety and health experts emerged. The only formal profession was in occupational medicine, but the doctors did not, by and large, get employment in the enterprises. Instead, a heterogeneous and complex institutional field of health and safety actors emerged in which experts were primarily employed "outside" the companies in consulting roles (A Kabel, Hasle, \& Limborg, 2007; Uhrenholdt Madsen, 2017). The internal company safety management was, in most companies, done by regular line managers and employee representatives with support from external advisors from, for example, the occupational health services. However, this has changed over the last decades. A process of "mainstreaming" OHS efforts in Denmark has been noticed (Hasle, Seim, \& Refslund, 2016). As a result of this mainstreaming and corresponding regulatory developments (Hasle, Limborg, Grøn, \& Refslund, 2017), the center of gravity within the OHS field has moved from external organizations into the companies themselves (Uhrenholdt Madsen, 2017). In this short essay, we describe this development, how it has shaped the outlook and approaches to health and safety in Denmark. 
To do this, we draw on a limited number of academic and popular historical sources that describe the development of the Danish health and safety experts and the lack of an actual professional category (Jacobsen, 2011; A Kabel et al., 2007; Anders Kabel, Limborg, Møller, Porse Sørensen, \& Kragh, 2008; Limborg et al., 1994; Limborg \& Voxted, 2008; Seim, Møller, \& Limborg, 2016; Uhrenholdt Madsen, 2017). In the essay, we seek to find the key "conjunctural" events (Mahoney, 1999) in Danish historical development that has led to the present state. Our aim is, thus, to outline the overall historical developments and factors, to analyze the present state of the Danish health and safety professionals, and to discuss whether a professionalization project is viable and, more importantly, desirable in the Danish context.

\section{Historical development of occupational health and safety professionals}

The emergence of health and safety professionals in Denmark is closely related to the development of regulatory approaches and frameworks. These are, in turn, connected to the development of the wider labor market structures in Denmark - the so-called "Danish model" of industrial relations. Thus, it is an area of regulation characterized by conflicts and compromises between different interests and positions. All of these are visible in the historical development of the occupational community of health and safety specialists and, today, in their daily tasks and roles inside the organizations. Since the passing of the first comprehensive "work environment law" in 1975, health and safety actors have had to navigate between interests of the state, the employers' associations, and the employees' representative organizations. These conflicts are visible in the founding, expansion, and closing of the most significant nexus of professionalization and competence development for health and safety specialists, the Occupational Health Services (A Kabel et al., 2007). Furthermore, they are visible in the day-to-day tasks within the organizational walls where the same conflicts and compromises can be seen in microformat.

Until the 1970s, Danish health and safety regulation followed the governance models of most of continental Europe and the UK by having a strong "command-control" character and a strong role for the state in the enforcement and development of the regulatory frameworks (Abrahamsson \& Johansson, 2013). However, the command-control models were criticized for being 1) inefficient regarding impact and 2) incomprehensible to the organizations that had to follow them (Aalders \& Wilthagen, 1997). In 1975, the first comprehensive health and safety law passed through parliament, and it signaled a more "reflexive" approach similar to international developments (Aalders \& Wilthagen, 1997; Teubner, 1983) from regulators to health and safety issues. This meant that the law and its provisions emphasized and sought to enforce processes and structures of organizational self-regulation. Furthermore, a legal innovation was the provision that employers have the duty to ensure a "safe and healthy work environment that at any given time is in concordance with the technical and social development in society" (WEA, 2010:§ ${ }^{1}$ ). Thereby, organizations had to implement proactive policies and participatory structures to meet this demand. Thus, the need for experts who could assess and improve risks to safety and health increased for the regulated organizations.

Originally, policymakers envisioned a supportive structure based on two "load-bearing columns" (Jacobsen 2013: 379). The first column focused on the employer responsibility to secure a safe and healthy work environment, a responsibility which built on a compulsory "safety organization" with employee participation. The second column consisted of knowledge support to the enterprises. The

\footnotetext{
${ }^{1}$ Ministry of Employment Consolidated Act No. 1072 of 7 September 2010
} 
main instrument was the foundation of a mandatory Occupational Health Service (OHS) in selected high-risk industries which were subsequently_in a rather long process - expected to reach the whole labor market. The OHS was originally modeled after the internal health services that a few large Danish companies already had established on a voluntary basis. In this way, the services were modeled after units rooted in occupational medicine and were mostly staffed by doctors and nurses (Limborg \& Voxted, 2008). However, variousfactors led to a much more heterogeneous staffing profile of the OHS. First of all, it was not possible to reach an agreement about salary and contracts in the collective bargaining rounds between the doctors and the services. (Anders Kabel et al., 2008). The employers considered the doctor to be far too expensive. However, and more importantly, a paradigm shift meant that a more technical-preventive approach to health and safety management were favored by trade unions and other influential voices in the debate (Limborg \& Voxted, 2008). This meant that the practices from occupational medicine monitoring the workforce for symptoms of health problems were discarded in favor of practices that involved technical solutions to health and safety risks and organizational preventive strategies. The then-popular slogan "The workplace is the patient—not the worker" best summarized the paradigm shift (Limborg, 2001).

The OHS was, thus, staffed primarily by three groups. One group include professionals with an education in either physio- or occupational therapy focusing on ergonomics. A professional degree in ergonomics did not exist and has not been established since, a second group comprised professionals with technical graduate degrees, such as engineers and architects, vocational degrees, such as lab technicians and some with a specialization as environmental technicians. A third group of OHS consultants came with various social science degrees from Danish universities;, over time, this group became dominated by psychologists. Thus, two ideational approaches shaped the composition of the OHS: 1) the technical-preventive approach based on the technical and ergonomic sciences, and 2) a more diffuse, but still significant, "spirit of '68" (Anders Kabel et al., 2008), that is, a critical and emancipatory outlook on workers' health and safety. The consequence of the two ideational approaches was that the consultants saw it as their primary tasks to "change the workplaces" through technical expertise and promotion of good intentions (Limborg \& Voxted, 2008). As evidenced by this process of emergence, the OHS was, from the start, characterized by multidisciplinarity and heterogeneity. Over a 20-year period, an array of involved parties (OHS units, employer associations, unions, and the authorities) discussed the establishment of a compulsory education which should secure the qualifications of this diverse group of OHS staff. The Work Environment Authority took the initiative to develop and market a basic training course of four weeks for OHS consultants from all fields. To some extent, this work laid out the fundamental understandings, values, methods of - and approaches to - the profession of being an OHS consultant. However, there was no support from the social partners or the authority to make this training course compulsory, and it lasted only for a limited time. Neither the Occupational Health Service institutions nor the consultants showed an interest in supporting a framework that could define values, quality demands, or direction in health and safety work. The pluralism was, in general, regarded as an advantage. Furthermore, both OHS units and employers saw compulsory education too costly.

Even with the lack of formal certification or accreditation, the OHS developed into the primary nexus for professional development and knowledge exchange for Danish health and safety profes- 
sionals (Limborg \& Voxted, 2008). Two important mechanisms in this development were the annual OHS conferences ${ }^{2}$ and the "Professional Association of OHS Employees" the latter of which, among other activities, organized expert committees on specific issues or challenges. It is likely that the lack of a core professional identity also meant that the approaches, skill sets, and focus of the OHS consultants were adaptable and agile in the face of changing demands of the wider labor market and regulatory structures. A study analyzes how the professional approaches changed over the service's almost 20 years of existence (Limborg, 2001). The study shows how the original focus on technical-preventive solutions was supplemented by a focus on organizational change processes and another focus on the integration of health and safety issues into central management systems. The former points to the increased importance of human resource (HR) issues and the emergence of well-being as an important category in both regulatory discussions (Rasmussen, Hansen, \& Nielsen, 2011) and the organizations (Holt Larsen, 2009). The latter is related to the tendency of mainstreaming health and safety (Jain, Leka, \& Zwetsloot, 2018) that was evident in both regulatory developments such as the passing of the EU Framework Directive (89/391/EEC) and the following Danish adaptation into national regulation 1992, as well as in increasing efforts by enterprises to act in a socially responsible manner. The new development also meant that professionals such as organizational psychologists and anthropologists increasingly were hired as OHS consultants (A Kabel et al., 2007).

During the 1990s, the OHS became a source of disagreement between employer associations and unions, and in 2003, the newly formed center-right coalition government decided to dissolve the OHS model and, instead, liberalize the provision for using external advisors. The consequence was that compulsory affiliation with the OHS was abolished and the OHS was forced to compete in a free but diminishing market for advice and consultancies. A number of the larger OHS units became private consultancy companies that still offered health and safety advice. A group of former OHS consultants sought employment in some of the new market entrants such as engineering consulting companies, health and safety departments, auditing companies providing certification processes, and management consultants facilitating HR issues such as organizational change and well-being strategies. Other former OHS employees comprising the most numerous such group were employed in larger Danish companies as internal work environment advisors (Anders Kabel et al., 2008).

The OHS became the formative and primary forum of professional development for the first generation of Danish health and safety professionals, and thus the OHS is still an important frame of reference for the generations of health and safety professionals staffing both private advisory companies and internal company health and safety functions alike.

\section{Institutional ties of occupational health and safety professionals}

To understand the character and composition of the diverse group of Danish health and safety professionals, we use a theoretical lens inspired by organizational institutionalism (Greenwood, Oliver, Lawrence, \& Meyer, 2017) with a specific focus on the concept of "institutional fields" (Wooten \& Hoffman, 2017). Institutional fields describe a collected group of organizations and actors that share both interpretative schemes and meaning and furthermore interact with each other more frequently than with "outsiders" (Scott, 1995). In this definition, the field of health and safety in Denmark describes the group of organizations and actors that interact more frequently with each other about

\footnotetext{
${ }^{2}$ First organized in 1983
} 
health- and safety-related issues (e.g., consultancy firms, trade unions, regulatory agencies, employers' associations, research institutions). It also is the common understandings and meanings they share (e.g., institutional logics about how to do health and safety work, created through the interaction of the different stakeholders (Uhrenholdt Madsen \& Hasle, 2017; Uhrenholdt Madsen \& Waldorff, n.d.)). As institutional fields emerge and become sedimented, an institutional infrastructure also emerges (Hinings, Logue, \& Zietsma, 2017). This infrastructure consists of regulations and laws, "field-configuring" events such as recurring conferences (Lampel \& Meyer, 2008), and specific officially constituted roles and tasks for organizations, to name just a few examples.

Many studies and cases within organizational institutionalism tell the same story. Organizations that discover a new challenge, regulatory inhibition, or risk to the core processes look to groups of professionals from "exotic" institutional fields to solve the problem. Thereafter, professional experts start to solve the organizational challenges based on the knowledge and values from the institutional field from which they originate. This leads to the incorporation of hitherto unknown normative values and practices into unrelated companies and organizations. As one example, US-based organizations hired civil-rights activists to staff their newly formed diversity management departments after President Kennedy enforced a new stricter regulation on diversity hiring (Dobbin, 2009). Another example is the increasing influence of former environmental activists in large chemical corporations' environmental departments, aiding the transition of the industry from reluctant to engaged participants in "corporate environmentalism" (Hoffman, 2001). Therefore, it is rather important how close internal organization actors relate to a certain institutional field. Studies show that the normative sense of belonging and the experience of the individual actors have a significant impact on how abstract policies are translated into concrete practices (see, e.g., (Gondo \& Amis, 2013; Lounsbury, 2001). Lounsbury (2001), for example, describes how it mattered greatly to the engagement and practices of the staff in newly formed recycling departments whether their backgrounds were from recycling activism and environmentalism, or whether the recycling tasks simply were given to existing staff departments such as technical or janitorial staff.

Turning again to the field of health and safety in Denmark, it consists of many different organizations and professional associations: regulatory agencies, the political system, employer associations, trade unions, work environment councils, the mandatory local "health and safety organizations" within all enterprises with more than 10 employees, the large group of health and safety consulting companies that have emerged in the wake of the OHS, the occupational medicine departments in the Danish hospitals, and finally, the professional associations. These actors together form the institutional field of health and safety. They all interact frequently with each other, and since the first comprehensive law passed in 1975, all of these actors have been granted or have created roles within the complex institutional infrastructure that has emerged over time. An idealized example of a field innovation process could be the following: The occupational medicine department in a Danish hospital discovers an emerging risk to employees. A public debate ensues within the field of work environment. Parliament passes a revision of the law after consultation with the social parties in the national "work environment council."" Thereafter, internal health and safety professionals implement the new legal demands in their companies after they have consulted with the participatory local work environment organization. Finally, organizational compliance is inspected by the

\footnotetext{
${ }^{3}$ Tr. Da. Arbejdsmiljørådet
} 
Labor Inspectorate (LI). ${ }^{4}$ If the organizational efforts do not comply with the law, the LI can order the organization to seek council from one of the many private certified health and safety counseling services to improve their efforts.

This short example illustrates the important roles that health and safety professionals play in diffusing and translating new health and safety efforts into concrete organizational practice, regardless of whether they work on the "inside" in specialized staff functions or on the "outside" in health and safety counseling companies. They are the "carriers of institutional meaning" from the field and into the organizations (Zilber, 2002: 235). A role as translators, however, requires the health and safety professionals to be immersed in both worlds - the external institutional field and the organizational subsystems. However, organizational actors who belong to occupational communities other than the traditional health and safety "field" are increasingly in charge of parts of the health and safety efforts inside the organizations (Uhrenholdt Madsen, 2017). This is due to both the "mainstreaming" of health and safety (Hasle, Seim, et al., 2016) and the composite character of health and safety regulation (i.e., it encompasses both psycho-social and physical risks). The increasing integration of health and safety management into central organizational spheres means that health and safety are folded into other organizational processes such as quality, environmental, or wider risk management processes (see, e.g., Hasle, Møller, et al., 2016; Jain et al., 2018; Uhrenholdt Madsen, 2017). In these examples, it is not given that the involved actors have any specific professional background in the institutional field of health and safety, but they still have to carry out the companies' primary health and safety efforts. Simultaneously, the increasing importance of psycho-social health and safety issues means that the HR departments in Danish enterprises are getting in to the management of large parts of health and safety issues but from their "well-being position" rooted in the HR management field and its theories and practices (Hasle \& Sørensen, 2013; Møller Christiansen \& Limborg, 2005).

Uhrenholdt Madsen (2017) describes how this development can be analyzed through the distinction between institutional closeness and institutional distance. A professional health and safety actor can have an orientation "close" to the institutional field of health and safety in Denmark where background, career path, and normative orientation all revolve around the OSH field and the values and concepts contained within it. On the contrary, a professional with a "distant" orientation is someone who is not rooted in the field, does not have a special affinity, or necessarily share the meanings and values diffused in the field. This type of professional necessarily works professionally but with OSH-related issues which are mainstreamed or integrated into the actor's main area such as HR management, quality management, or risk management and planning.

\section{Tasks and activities for occupational health and safety professionals}

In international literature (see, e.g., INSHPO, 2017), the distinction between safety "practitioner" and safety "professional" is clearly demarcated in terms of their educational background and their

\footnotetext{
${ }^{4}$ Tr. Da. Arbejdstilsynet
} 
roles and tasks within the organizations. However, in the Danish context, this clear demarcation of responsibilities and competencies does not reflect the empirical reality. As described in previous sections of this paper, the professional OSH actors in Denmark are characterized by heterogeneity and diversity when it comes to biographies and educational accreditations. Furthermore, recent empirical studies of Danish OSH professionals suggests that the tasks and responsibilities of OSH professionals do not follow this distinction either. Seim and colleagues (2016) describe how the roles of professionals cannot be said to be either strategic or operational, but that these two types of tasks, in many cases, fall on the same professionals. The authors point out how this is determined not by background and education but by the industry and organizational reality of the professional in question. Furthermore, Uhrenholdt Madsen (2017: 164) also describes how some professionals in largescale bureaucratic organizations mainly prefer to orient themselves toward the day-to-day operational tasks, even though their official organizational roles designated them as strategic staff managers. Thus, we group the different tasks carried out by OSH professionals into three overall ideal types. Each has a "strategic" and a "day-to-day dimension to it, as also described by Brun and Loiselle in their model of safety practices (2002). For each of the categories, we will describe what "institutionally distant" organizational actors are potential competitors for the OSH professionals for this particular type of task.

INSERT FIGURE 1 ABOUT HERE $\gg$ Figure 1: OSH-professionals and their competitors $<<$

First, a group of tasks for Danish health and safety professionals can be considered "operational" (Seim et al., 2016). These tasks are mainly concerned with integrating the health and safety efforts into the overall operations of the organizations. These tasks ensure that health and safety issues and risks do not hinder production, growth, or new business opportunities. The operational health and safety tasks are defined by the overall operational issues facing any organization in relation to stakeholders such as customers and suppliers or in relation to the efficiency of internal technology and processes. These tasks thus involve both making sure that concrete risks are solved in a manner that does not hinder operations and makes the same operational processes as risk-free as possible, that is, through concrete ergonomic interventions, the introduction of preventive equipment, or through the inspection and potential adjustments of machinery or building issues. The operational tasks have to be carried out in close coordination with the organization's main operational activities in the productive cores. Therefore, line managers especially can replace OSH professionals in carrying out these issues. Also, other actors such as LEAN consultants or production planners can potentially integrate OSH-related issues into their portfolios. Both cases will, presumably, lead to a lack of specific knowledge of risks and prevention strategies.

Another important type of task for Danish health and safety professionals is the "systematizing" tasks (Seim et al., 2016). Professionals have to create and maintain some form of systems to conform to legal standards in the Danish legislation. They must carry out mandatory workplace assessments and the registration of accidents, incidents, and sick leave. Furthermore, an increasing number of organizations choose to use certified work environment management systems such as OHSAS18001 to ensure compliance and development of health and safety systems in the organization (Uhrenholdt Madsen, Kirkegaard, Hasle, \& Dyreborg, 2018). These tasks involve creating and expanding health and safety systems within the organizations and making sure that the systems are maintained and functioning. Systematizing tasks are closely related and wholly compatible with 
other types of certified management systems (Pagell, Johnston, Veltri, Klassen, \& Biehl, 2014). With the adoption of OHSAS18001, workplace assessment and data registration schemes can also be subsumed under the auspices of, for example, environmental staff functions or the quality department as the standards for each of these are both older and more widely spread. Therefore, it is likely that the certified management systems for quality, environment, or both will already be in place when an organization adopts the OHSAS18001 standard (Jørgensen, Remmen, \& Mellado, 2006). Data registration of accidents, incidents, and sick leave can also fall under a broader risk management department's organizational jurisdiction. Finally, the adoption of certified management systems also introduces external professional auditors from certification agencies as important actors in the health and safety issues of companies (Hohnen \& Hasle, 2018).

Finally, a number of tasks can be grouped into the category of "processual" tasks (Seim et al., 2016). These tasks involve making sure that internal processes surrounding health and safety are in place and carried out within the organizations. Examples include the processes concerned with running and driving efforts in the mandatory participatory work environment organizations ${ }^{5}$ that all Danish organizations of a certain size must have in place. In this way, the health and safety professionals are often tasked with making sure that cooperation and common problem-solving in these participatory structures are running smoothly. Other types of tasks in this category are organizationwide processes to improve psycho-social health and safety conditions, for example, the work with social capital interventions (Seim et al., 2016; Uhrenholdt Madsen, 2017). These tasks can be integrated into broader HR strategies and thus be carried out by consultants from these staff functions as well (Uhrenholdt Madsen, 2017). Also, external actors such as management consultants and process consultants can be involved in processual health- and safety-related tasks.

\section{Discussion}

What we can conclude is that there are health and safety professionals in Danish enterprises. However, they need a profession in which to develop and grow. At the beginning of this essay, we asked whether a further professionalization project for Danish OSH professionals is a) "viable" vis a vis the present situation and b) "desirable" to strengthen the OSH efforts in Danish enterprises and organizations.

As we describe in previous sections, the main vehicle for forging and developing a professional identity as "OSH professionals" in Denmark was for many years the Occupational Health Services. The OHS were, from the start, multidisciplinary with employees with various professional backgrounds. The parties behind the agreement could not agree on any mandatory certification, education, or post-graduate course for employees in the services. Therefore, the identity of the professionals was mainly centered around the topic and the issue at hand, occupational health and safety, and less on any commonalities in approach or methodology. The Occupational Health Services were thus a proverbial "big-tent" organization. Furthermore, the broad and inclusive definition of "work environment" in the Danish legal framework meant that differentiated and specialized disciplinary knowledge is needed to solve Danish organizations' OSH-related issues properly. This also means that a professionalization process in Denmark must take into consideration the width and diversity

\footnotetext{
${ }^{5}$ Formerly known as Safety Organizations
} 
that today still characterizes the professional backgrounds of actors who work with OSH issues in Danish companies. A professionalization process must seek to create a common framework of shared values and shared knowledge on occupational health and safety in enterprises while including groups as diverse as chemical engineers, occupational psychologists, and business-school graduates. In short, it must be a big-tent profession based on commonality in values and mission and with a shared occupational identity more than a shared educational background.

However, from our point of view, it is clear that recent developments have made a continuous professionalization project in the Danish OSH field a desirable development. During the last two decades, occupational health and safety have moved from the so-called "sidecar" (where OSH is somewhat removed from the central strategic and operational processes within the Danish organizations) and into the organizational mainstream as described in a previous section. This process undoubtedly creates a stronger awareness and better integration of OSH considerations into day-to-day operations of organizations. However, an unintended consequence of the mainstreaming efforts can be as we describe in this essay, that the OSH tasks will be carried out by other organizational actors, who do not necessarily share the affinity, institutional closeness, or the broad health and safety capabilities that actors from within the traditional OSH field have. Therefore, there is a risk of atomization of the OSH tasks within the companies so that the processual tasks are carried out by the HR staff, operational tasks are carried out by line managers, and the systematic tasks are subsumed under the quality management departments jurisdiction. An illustration of this could be the fact that many of these actors in the construction sector where the role is widespread are referred to as QEO officers (Quality, Environment, and OSH). In this way, a risk will be that there are no actors within Danish organizations who have OSH as their main concern and who have strong ties to the field and its configuring events such as conferences and peer networks. Thus, the organizations' ties with the OSH field, and thus the translatory capacity (Uhrenholdt Madsen et al., 2018) within the organizations, can be somewhat diluted.

Strengthening an actual OSH profession in Denmark could counteract the tendency toward atomization. However, as stated earlier, the professionals would have to understand the operational and strategic processes in which they must operate. The INSHPO capability framework (INSHPO, 2017) makes two assumptions that do not fit the DanishDanish context as we have described above. First, the separation between "practitioner" and "professional" is not necessarily a salient distinction in the Danish context. As we have described, the operational, systematic, and processual roles will have both "practical" and more strategic aspects that will need to be tended to. Instead, we propose that a professional project will take a point of departure in the typology of roles we have described. This way, OSH professionals will share a common core of knowledge and values but will then have specialized knowledge in either the processual, operational, or systematic realm. Thus, OSH professionals will share the institutional closeness to the field that we believe is key to maintaining a strong OSH presence in the organizations while they can cooperate closely with or be part of other staff departments such as HR, quality, or line management. In this way, there is a place for OSH professionals inside the organizations whether the organizations have a specialized OSH department or not or have segmented various OSH tasks into other staff departments (see, e.g., (Uhrenholdt Madsen, 2017). A profession created after these principles would still make sure that all professionals shared a core of OSH knowledge and values with other OSH actors. However, a strong mechanism for this is missing as there currently is no official training or education in OSH available at either the bachelor or a master level. 


\section{Bibliography:}

Aalders, M., \& Wilthagen, T. (1997). Moving Beyond Command-and-Control: Reflexivity in the Regulation of Occupational Safety and Health and the Environment. Law and Policy, 19(4), 415-443.

Abrahamsson, L., \& Johansson, J. (2013, January 1). One Hundred Years of Inertia: An Exposé of the Concept of the Psychosocial Work Environment in Swedish Policy and Research. Nordic Journal of Working Life Studies. http://doi.org/http://dx.doi.org/10.19154/njwls.v3i1.2518

Brun, J.-P., \& Loiselle, C. D. (2002). The roles, functions and activities of safety practitioners: the current situation in Québec. Safety Science, 40(6), 519-536. http://doi.org/http://dx.doi.org/10.1016/S0925-7535(01)00018-2

Dobbin, F. R. (2009). Inventing Equal Opportunity. Princeton University Press. Retrieved from https://books.google.dk/books?id=GCAz25CZKoIC

Evetts, J. (2011). A new professionalism? Challenges and opportunities. Current Sociology, 59(4), 406-422. http://doi.org/10.1177/0011392111402585

Freidson, E. (2001). Professionalism - A Third Logic. Polity Press.

Giddens, A. (1989). Sociology. Polity Press.

Gondo, M. B., \& Amis, J. M. (2013). Variations in Practice Adoptions : The Roles of Counscious Reflection and Discourse. Academy of Management Review, 38(2), 229-247.

Greenwood, R., Oliver, C., Lawrence, T. B., \& Meyer, R. E. (2017). The Sage Handbook of Organizational Institutionalism. (R. Greenwood, C. Oliver, T. B. Lawrence, \& R. E. Meyer, Eds.) (2nd ed.). Sage Reference.

Hale, A., \& Harvey, H. (2012). Certification of safety professionals: Emerging trends of internationalisation. In Proceedings of the 6th International Conference of Working on Safety Network "Towards Safety Through Advanced Solutions."

Hasle, P., Limborg, H. J., Grøn, S., \& Refslund, B. (2017). Orchestration in work environment policy programs. Nordic Journal of Working Life Studies (Forthcoming), 7(3), 43-62.

Hasle, P., Møller, N., Refslund, B., Limborg, H. J., Nielsen, K. T., Bramming, P., \& Seim, R. (2016). Virkemidler $i$ arbejdsmiljøindsatsen - Afslutningsrapport fra Center for forskning $i$ virkemidler og arbejdsmiljøindsatser (CAVI) Hasle,Peter - Møller,Niels - Refslund,Bjarke AU - Limborg,Hans Jørgen AU - Nielsen,Klaus T. AU.

Hasle, P., Seim, R., \& Refslund, B. (2016). From employee representation to problem-solving Mainstreaming OHS management. Economic and Industrial Democracy (Forthcoming). http://doi.org/10.5465/amr.2010.0312

Hasle, P., \& Sørensen, O. H. (2013). Employees as Individually and Collectively Acting SubjectsKey Contributions from Nordic Working Life Research. Nordic Journal of Working Life 
Studies, 3(3), 9. http://doi.org/10.19154/njwls.v3i3.3009

Hinings, C. R. (BOB), Logue, D., \& Zietsma, C. (2017). Fields, Institutional Infrastructure and Governance. In R. Greenwood, C. Oliver, T. B. Lawrence, \& R. E. Meyer (Eds.), The Sage Handbook of Organizational Institutionalism (2nd ed., pp. 163-190). Sage Reference.

Hoffman, A. J. (2001). From Heresy to Dogma: An Institutional History of Corporate Environmentalism. Stanford: Stanford University Press.

Hohnen, P., \& Hasle, P. (2018). Third party audits of the psychosocial work environment in occupational health and safety management systems. Safety Science, 109, 76-85. http://doi.org/https://doi.org/10.1016/j.ssci.2018.04.028

Holt Larsen, H. (2009). HRM: Ledelse af virksomhedens menneskelige ressourcer [HRM: Management of the human resources of the firm]. Ledelse Og Erhvervsøkonomi [Management and Business], (4), 7-19.

INSHPO. (2017). The Occupational Health and Safety Professional Capability Framework A Global Framework for Practice.

Jacobsen, K. (2011). Velfcerdens Pris: Arbejderbeskyttelse og Arbejdsmiljø Gennem 150 år [The Price of Welfare: Workers Protection and Work Environment Through 150 years]. Copenhagen: Gads Forlag.

Jain, A., Leka, S., \& Zwetsloot, G. I. J. M. (2018). Mainstreaming Health, Safety and Well-Being. In A. Jain, S. Leka, \& G. I. J. M. Zwetsloot (Eds.), Managing Health, Safety and Well-Being: Ethics, Responsibility and Sustainability (pp. 175-220). Dordrecht: Springer Netherlands. http://doi.org/10.1007/978-94-024-1261-1_6

Jørgensen, T. H., Remmen, A., \& Mellado, M. D. (2006). Integrated management systems - Three different levels of integration. Journal of Cleaner Production, 14(8), 713-722. http://doi.org/10.1016/j.jclepro.2005.04.005

Kabel, A., Hasle, P., \& Limborg, H. J. (2007). Occupational health services in Denmark - the rise and fall of a multidisciplinary and preventive approach. Policy and Practice in Health and Safety, 5(Suppl.), 25-38.

Kabel, A., Limborg, H. J., Møller, N., Porse Sørensen, N., \& Kragh, D. (2008). Fra Engagement Til Styring: Arbejdsmiljøarbejdets historie fra dem der var med [From Engagement to Control: History of the work environment efforts from those who were there]. Copenhagen: Selskab for Arbejdsmiljø [Society for Work Environment].

Lampel, J., \& Meyer, A. D. (2008). Guest Editors' Introduction: Field Configuring Events as Structuring Mechanisms: How Conferences, Ceremonies and Trade Shows Constitue New Technologies, Industries and Markets. Journal of Management Studies, 45(6), 1025-1035. http://doi.org/10.1111/j.1467-6486.2008.00787.x

Limborg, H. J. (2001). The professional working environment consultant? A new actor in the health and safety arena. Human Factors and Ergonomics in Manufacturing, 11(2), 159-172. http://doi.org/10.1002/hfm.1006

Limborg, H. J., Porsgaard Nielsen, M., Viskum, S., Saabye, A., Sæbye, U., \& Langaa Jensen, P. (1994). Arbejdsmiljøprofessionelle i Danmark: Kvalifikationer og Uddannelse [Work Environment Professionals in Denmark: Qualifications and Education]. 
Limborg, H. J., \& Voxted, J. (2008). Arbejdsmiljørådgivningens fremtid - set $i$ historisk lys [The Future of Work Environment Counselling - In a historical light].

Lounsbury, M. (2001). Institutional sources of practice variation: Staffing college and university recycling programs. Administrative Science Quarterly, 46(1), 29-56. http://doi.org/10.2307/2667124

Mahoney, J. (1999). Nominal, ordinal, and narrative appraisal in macrocausal analysis 1. American Journal of Sociology. Retrieved from http://www.jstor.org/stable/10.1086/210139

Møller Christiansen, J., \& Limborg, H. J. (2005). Private virksomheders håndtering af det psykiske arbejdsmiljø [Private companies handling of the psychosocial work environment].

Muzio, D., \& Kirkpatrick, I. (2011). Introduction: Professions and organizations - a conceptual framework. Current Sociology, 59(4), 389-405. http://doi.org/10.1177/0011392111402584

Pagell, M., Johnston, D., Veltri, A., Klassen, R., \& Biehl, M. (2014). Is safe production an oxymoron? Production and Operations Management, 23(7). http://doi.org/10.1111/poms.12100

Provan, D. J., Dekker, S. W. A., \& Rae, A. J. (2017). Bureaucracy, influence and beliefs: A literature review of the factors shaping the role of a safety professional. Safety Science, 98(Supplement C), 98-112. http://doi.org/https://doi.org/10.1016/j.ssci.2017.06.006

Rasmussen, M. B., Hansen, T., \& Nielsen, K. T. (2011). New tools and strategies for the inspection of the psychosocial working environment: The experience of the Danish Working Environment Authority. Safety Science, 49(4), 565-574. http://doi.org/10.1016/j.ssci.2010.06.002

Scott, W. R. (1995). Institutions and Organizations. SAGE Publications.

Seim, R., Møller, N., \& Limborg, H. J. (2016). Professionelle og medarbejderrepræsentanter - nye roller i arbejdsmiljøarbejdet [Professionals and Employee Representatives - New roles in the working environment efforts]. Tidskrift for Arbejdsliv [Journal for Working Life], 18(1), 1833.

Teubner, G. (1983). Substantive And Reflexive Elements in Modern Law. Law \& Society Review', 17(2), 239-286. http://doi.org/10.2307/3053348

Uhrenholdt Madsen, C. (2017). Safe Hands - Institutional Dynamics of Work Environment Management. Copenhagen: Aalborg University Press.

Uhrenholdt Madsen, C., \& Hasle, P. (2017). Commitment or Compliance?-Competing institutional logics in the field of OHS management. Nordic Journal of Working Life Studies, 7(S2).

Uhrenholdt Madsen, C., Kirkegaard, M. L., Hasle, P., \& Dyreborg, J. (2018). "To Him Who Has, More Will Be Given..."-A Realist Review of the OHSAS18001 Standard of OHS Management. In S. Bagnara, R. Tartaglia, S. Albolino, T. Alexander, \& Y. Fujita (Eds.), Proceedings of the 20th Congress of the International Ergonomics Association (IEA 2018) (pp. 140-149). Cham: Springer International Publishing.

Uhrenholdt Madsen, C., \& Waldorff, S. B. (n.d.). Between advocacy, compliance and commitment: A multilevel analysis of institutional logics in work environment management (Forthcoming). 
Scandinavian Journal of Management (Forthcoming).

Van Maanen, J., \& Barley, S. R. (1984). Occupational Communities: Culture and Control in Organizations. Research in Organizational Behavior, 6, 287-365.

Wooten, M., \& Hoffman, A. J. (2017). Organizational Fields: Past, Present and Future. In R. Greenwood, C. Oliver, T. B. Lawrence, \& R. E. Meyer (Eds.), The SAGE Handbook of Organizational Institutionalism (2nd ed., pp. 55-75). Sage Reference.

Zilber, T. B. (2002). Institutionalization as an Interplay between Actions, Meanings, and Actors: The Case of a Rape Crisis Center in Israel. The Academy of Management Journal, 45(1), 234 254. http://doi.org/10.2307/3069294 